\title{
Searching for change: Scottish stop and search powers
}

\author{
Genevieve Lennon*
}
A. INTRODUCTION
B. SCOTTISH STOP AND SEARCH POWERS
(1) Suspicion-based statutory powers
(2) Suspicionless statutory powers
(3) Non-statutory powers
C. COMPATIBILITY WITH THE ECHR
(1) Suspicionless statutory powers
(2) Suspicion-based statutory powers
(3) Non-statutory powers
D. CONCLUSION

\section{A. INTRODUCTION}

In numerous countries, stop and search powers are an open sore upon police-community relations, one which is increasingly being challenged through the courts. In the USA, the discriminatory practices associated with stop and search powers led to the coining of terms such as "driving while black" (more recently joined by "flying while brown"). In 2013, the District Court for the Southern District of New York held, inter alia, that the City of New York was liable for their indifference towards the New York City Police Department's widespread practice of stop and frisk which violated the fourth and fourteenth amendments of the Constitution. ${ }^{1}$ In England stop and search practices were a commonly cited factor in the

\footnotetext{
* Chancellor's Fellow, University of Strathclyde. I am grateful to Dr Claire McDiarmid and Prof Kenneth Norrie for their insights regarding children's capacity to consent and to the anonymous reviewer for their constructive comments. The usual caveats apply.

${ }^{1}$ Floyd et al $v$ the City of New York et al 959 F Supp 5d 540 (2013).
} 
Tottenham riots, and a stop, search, and arrest power was the catalyst for the Brixton riots. ${ }^{2}$ Since 2010, stop and search has come before the European Court of Human Rights (ECtHR) in two cases, one from the Netherlands, the other from the UK. ${ }^{3}$ Other examples can be found across the globe. ${ }^{4}$

By contrast, until very recently stop and search was a non-issue in Scotland. A senior inspector from Her Majesty's Inspectorate of Constabulary in Scotland (HMICS) is quoted by Murray as stating that:

Stop and search was never in my years at HMIC Scotland raised as an issue. And that in itself is curious ... The Scottish Human Rights Commission didn't raise it, the Scottish Government didn't raise it, there was no clarion call from the media for it. The police services themselves, perhaps understandably because nobody's asking them, didn't raise it. ${ }^{5}$

This is indeed curious given the broadly similar powers and crime trends across the UK. What is even more surprising is the fact that since the mid-2000's the rates of stop and search per capita in Scotland have significantly exceeded those in England and Wales, peaking in 2012/13 with rates of stop and search seven times higher in Scotland. ${ }^{6}$ The publication of Murray's seminal report on Scottish stop and search in January 2014 catapulted the issue into the spotlight, and stop and search (particularly the non-statutory variety) has become one of the major issues facing Police Scotland. ${ }^{7}$ In addition to significant media interest, ${ }^{8}$ there have

\footnotetext{
2 The power was the Metropolitan Act 1839, s 66. Lord Scarman, The Brixton Disorders 1012 April 1981 (Cmnd 8427: 1981); Riots, Communities and Victims Panel, Five days in August (An Interim Report on the 2011 English riots) (2011).

${ }^{3}$ Colon v the Netherlands (2012) 55 EHRR SE5; Gillan v United Kingdom (2010) 50 EHRR 45.

${ }^{4}$ See L Weber and B Bowling, Stop and Search: Police Power in a Global Context (2013) for a discussion of stop and search in Hungry, Japan, South Africa, India, Australia, Canada, and the Netherlands.

${ }^{5}$ Cited in K Murray, "Stop and search in Scotland: An evaluation of police practice" (2014) SCCJR 1.

${ }^{6}$ K Murray, "Stop and search in Scotland: A post reform overview" (2015) SCCJR.

${ }^{7}$ Murray (n 5).

${ }^{8}$ See, e.g., P Hutcheon, "Nearly one in every five Glaswegians subjected to stop and search" (The Herald, 21 June 2015); S Carrell, "Police stop and search rates in Scotland four times higher than in England" (The Guardian, 17 January 2014).
} 
been inquiries by the HMICS, the Scottish Police Authority and the Advisory Group on Stop and Search, established by the Scottish Government in March 2015. ${ }^{9}$

While the scholarship on Scottish stop and search is burgeoning, significant gaps remain. This article will contribute to redressing this void by examining the legal basis for and compatibility of Scottish stop and search powers with the European Convention on Human Rights (ECHR). The analysis will highlight numerous failings in the current regime, some of which reveal incompatibility, some of which suggest that incompatible practices may occur (although there is insufficient data to confirm or dispel the thesis), others which "merely" evidence very poor practice.

The crux of all debates on stop and search is how to balance the discretion inherent in the power with the requirements of lex certa while also ensuring sufficient safeguards against abuse. In the language of the ECHR, how to ensure the power is prescribed by law? On the one hand, this discretion is an inherent and necessary part of the powers, and speaks to the primary purpose of stop and search: to permit the police a power, short of arrest, whereby they can confirm or allay suspicions of a person's involvement in criminality, thereby enabling the detection of crime. ${ }^{10}$ This discretion, evident in all the powers, whether statutory or non-statutory, is further complicated by the location of stop and search within street policing, which is typically of "low visibility" and where the "norms and practices of the street level police officer take priority over outside regulation". ${ }^{11}$ The discretion must be sufficiently bound to ensure the instruments are prescribed by law. This requirement of the ECHR, which reflects general principles of the rule of law, ${ }^{12}$ has three aspects: (1) the power must have a basis in law; ${ }^{13}$ (2) it must be sufficiently foreseeable so that people understand the potential consequences and can regulate their actions accordingly, ${ }^{14}$ and (3) there must be

\footnotetext{
${ }^{9}$ HMICS, Audit and Assurance Review of Stop and Search: Phase 1 (2015); Scottish Police Authority, Scrutiny Review on stop and search (2014); Advisory Group on Stop and Search, The Report of the Advisory Group on Stop and Search (2015).

${ }^{10}$ Report of the Royal Commission on Criminal Procedure (Cmnd 8092: 1981) ("RCCP"). Police and Criminal Evidence Act 1984 ("PACE"), Code A, para 1.4.

${ }^{11}$ A Sanders and R Young, "Police Powers" in T Newburn (ed), Handbook of Policing (2003) 229.

${ }^{12}$ See, for example, J Raz, "The rule of law and its virtue" (1977) 93 LQR 195.

${ }^{13}$ Malone v United Kingdom (1991) 13 EHRR 448.

${ }^{14}$ Sunday Times $v$ United Kingdom (1979) 2 EHRR 245.
} 
"a measure of protection in domestic law against arbitrary interferences by public authorities". 15

Routine stop and search engages the right to a private life under Article 8 of the ECHR. ${ }^{16}$ Depending on the circumstances, Articles 10 and 11 (freedom of assembly and speech) and Article 14 (prohibition on the discriminatory application of the ECHR rights and freedoms) may also be engaged. Despite the ECtHR's suggestion in Gillan v United Kingdom that the coercive nature of the stop was "indicative of a deprivation of liberty", it seems unlikely that Article 5 is engaged by a routine stop and search. ${ }^{17}$ The "threshold" where a restriction on movement, protected under Protocol 4, Article 2 (which has not been ratified by the UK), becomes a deprivation of liberty is notoriously amorphous, being "merely one of degree or intensity, and not one of nature or substance". ${ }^{18}$ Cases such as Secretary of State for the Home Department $v M B$, where a fourteen hour curfew under a control order was held not to be a deprivation of liberty, ${ }^{19}$ suggest that, coercion notwithstanding, a routine stop and search would not cross the threshold. ${ }^{20}$

As well as being prescribed by law, stop and search powers must be exercised proportionately in order to comply with the ECHR. This article will focus on the former requirement for two reasons. First, it has been the key issue before the courts and precedes questions of proportionality: if an instrument is not prescribed by law, it cannot be proportionate. Second, greater detail on the practice of stop and search is needed to assess proportionality properly. The data and research currently available is insufficient for this task in relation to some of the categories of stop and search. ${ }^{21}$

This article will first outline the powers of stop and search in Scotland. It will then examine in turn the compatibility of each category of stop and search with the ECHR:

${ }^{15}$ Olsson v Sweden (1989) 11 EHRR 259, para [61]. See also Gillan.

${ }^{16}$ Gillan; Colon.

${ }^{17}$ Gillan para [57]. Cf $R$ (on the application of Gillan) $v$ Commissioner of Police for the Metropolis [2006] 2 AC 307, [2006] UKHL 12, para [26] and Roberts $v$ Commissioner of Police of the Metropolis [2014] 1 WLR 3299, [2014] EWCA Civ 69, para [13].

${ }^{18}$ Guzzardi v Italy (1981) 3 EHRR 333, para [93].

${ }^{19}$ [2007] UKHL 46. By contrast, sixteen hours curfew was a deprivation of liberty: Secretary of State for the Home Department v JJ [2007] UKHL 45. See also: Trijonis v Lithuania (2005) app no 2333/02, judgment of 17 March 2005 regarding house arrest.

${ }^{20}$ Cf D Mead, "The likely effect of the Human Rights Act on everyday policing decisions in England and Wales" (2000) 5 JCL 5.

${ }^{21}$ Although the evidence base is growing rapidly. See Murray (nn 5 and 6); M O’Neill, L Aston, and A Krause, "The Fife Division (Police Scotland) Stop and Search Pilot Evaluation: Findings and Recommendations" (2015); HMICS (n 9). 
suspicionless statutory powers, suspicion-based statutory, and the non-statutory power. The key issue in relation to the suspicionless statutory powers is whether the system of authorisation sufficiently balances the virtually unfettered discretion of officers regarding who to select to stop. Suspicion-based statutory powers raise concerns regarding the definition of reasonable suspicion, the requirements relating to officers' conduct during the encounter and systems of review more generally. In addition to issues regarding consent, the absence of safeguards to limit the risk of the arbitrary deployment of the non-statutory power raises significant concerns.

\section{B. SCOTTISH STOP AND SEARCH POWERS}

\section{(1) Suspicion-based statutory powers}

Stop and search powers fall into two types: statutory and non-statutory. The former may be further sub-divided into suspicionless powers and those triggered by reasonable suspicion. To begin with this final category, which constitutes the vast majority of the statutory class, the powers tend to follow a similar formula: the police may stop and search a person if they reasonably suspect an offence has been, is being, or is about to be committed, or that the person is carrying a prohibited article. Some powers extend also to vehicles or vessels, drivers and passengers. The statutes use a variety of wording, such as "reasonable suspicion", "reasonable grounds", and "reasonable cause". ${ }^{22}$ Because there is no practicable difference between these phrases, and for the sake of clarity, this article will refer only to reasonable suspicion.

There are stop and search powers in relation to persons suspected of "core" criminal offences: possession of or carrying an offensive weapon ${ }^{23}$ in a public place ${ }^{24}$ or on school premises ${ }^{25}$ or of an article with a blade or point, again in a public place or on school

\footnotetext{
${ }^{22}$ E.g., "reasonably suspects": Terrorism Act 2000 s 43; "reasonable grounds": Criminal Law (Consolidation) (Scotland) Act 1995 s 48; "reasonable cause": Wildlife and Countryside Act 1981 s 19.

23 "Offensive weapon" is defined in the Criminal Law (Consolidation) (Scotland) Act $1995 \mathrm{~s}$ 47(4) as being any article that is made or adapted for use for causing injury to a person or intended to cause such injury.

${ }^{24}$ Criminal Law (Consolidation) (Scotland) Act 1995 s 48.

${ }^{25}$ Ibid s 49B.
} 
premises; ${ }^{26}$ possession of controlled drugs, ${ }^{27}$ prohibited fireworks, ${ }^{28}$ or stolen property (including property constituting evidence of the commission of theft, ${ }^{29}$ or located within aerodromes and vehicles and aircraft within aerodromes); ${ }^{30}$ possession of goods which are liable to forfeiture under the Customs and Excise Acts $1979 ;{ }^{31}$ or on suspicion of a person's being a terrorist, or in relation to a vehicle reasonably suspected of being used for terrorism. ${ }^{32}$ Of note, where these powers are not UK wide there are equivalent powers in England, Wales and Northern Ireland, with the exception of stopping and searching for evidence of the commission of theft, which is unique to Scotland. ${ }^{33}$

A number of powers exist in relation to wildlife and environmental offences. These grant constables the power to stop and search a person whom they suspect has committed or is committing an offence under Part I of the Wildlife and Countryside Act 1981, ${ }^{34}$ the Protection of Badgers Act 1992, ${ }^{35}$ Part 6 of the Marine (Scotland) Act 2010, ${ }^{36}$ or Part 2 of the Nature Conservation (Scotland) Act 2004. ${ }^{37}$ Police may also stop and search any person suspected of hunting wild animals with dogs. ${ }^{38}$

Finally, under the Criminal Law (Consolidation) (Scotland) Act 1995 section 21, the police may stop and search any person they suspect of being in possession of alcohol or a flare, or being drunk at, while entering, or while in, a designated sporting event. They may also stop and search public service vehicles and vehicles which can carry over eight persons that are conveying passengers to a designated sporting event and are suspected of carrying drunk people or alcohol. This article will not discuss alcohol confiscation powers as they do not expressly include a power to search.

\footnotetext{
${ }^{26}$ Ibid s 50.

${ }^{27}$ Misuse of Drugs Act 1971 s 23.

${ }^{28}$ Fireworks Act 2003 s 11 A.

${ }^{29}$ Civic Government (Scotland) Act 1982 s 60.

${ }^{30}$ Aviation Security Act 1982 s 24B.

${ }^{31}$ Customs and Excise Management Act 1979 ss 163-164A.

32 Terrorism Act 2000 ss 43, 43A.

${ }^{33}$ Although PACE s 1(7)(b) is similar.

${ }^{34}$ Wildlife and Countryside Act 1981 s 19.

${ }^{35} \mathrm{~S} 11$

${ }^{36} \mathrm{~S} 126$. Part 6 concerns the conservation of seals.

${ }^{37} \mathrm{~S} 43$

${ }^{38}$ Protection of Wild Mammals (Scotland) Act 2002 s 7.
} 


\section{(2) Suspicionless Statutory Powers}

The second type of statutory powers permits suspicionless stop and search in authorised areas. There are two such powers, both UK wide: section 60 of the Criminal Justice and Public Order Act 1994 and section 47A of the Terrorism Act 2000.

An inspector or more senior officer may authorise the use of section 60 of the 1994 Act if such officer reasonably believes that in any locality in the police area incidents involving serious violence may take place, and the authorisation is expedient to prevent their occurrence or that persons are carrying dangerous instruments or offensive weapons without good reason. ${ }^{39}$ Thereafter a constable in uniform may, without suspicion, stop any person or vehicle within the locality and search them, the vehicle, and any passenger for offensive weapons or dangerous instruments. ${ }^{40}$ The authorisation may last up to twenty-four hours and can be extended by a further twenty-four hours if it appears to a superintendent or more senior officer that it is expedient to do so. ${ }^{41}$

The trigger for authorisation under section 47A(1) of the 2000 Act is that an assistant chief constable or chief constable reasonably suspects that an act of terrorism will take place and the authorisation is necessary to prevent it. The authorisation must be approved by the Secretary of State within forty-eight hours or it will lapse, while not affecting the legality of actions taken in the interim. ${ }^{42}$ The authorisation may last up to fourteen days and extend up to the entire force area, although it should be no longer nor geographically broader than necessary. ${ }^{43}$ Once authorised, a uniformed officer may stop a person and search for evidence that such person is a terrorist or stop a vehicle and search it for evidence that it is being used in connection with terrorism. ${ }^{44}$

There is a third suspicionless stop and search power (under Schedule 7 to the 2000 Act) which will not be further discussed here, for three reasons. ${ }^{45}$ First, it applies to ports and

\footnotetext{
${ }^{39}$ Note that an additional limb in England and Wales permits an authorisation if the officer reasonably believes that (a) an incident involving serious violence has taken place, (b) a dangerous instrument or offensive weapon used in the incident is being carried in the locality, and (c) the authorisation is expedient to find such item (s 60(1)(aa)).

${ }^{40} 1994$ Act s 60(4).

411994 Act ss 60(1), (3).

422000 Act sch 6B para 7.

${ }^{43} 2000$ Act sch $6 \mathrm{~B}$ para 6.

442000 Act ss 47A(2)-(6).

${ }^{45}$ For details on the use and extent of sch 7, see C Walker, Blackstone's Guide to the AntiTerrorism Legislation (2014) paras 5.115-5.140 passim. The Schedule's compatibility with the ECHR was recently challenged in $R$ (Miranda) $v$ Secretary of State for the Home
} 
borders, where more stringent and onerous conditions of passage are traditionally applied and persons travelling may be viewed as having consented to the search as a condition of travel. Second, the power may be exercised by examining officers, not simply the police. Third, it provides a plethora of powers extending beyond "mere" stop and search. ${ }^{46}$

\section{(3) Non-Statutory Powers}

The final category, unique to Scotland within the UK, is non-statutory or "consensual" stop and search. There is no requirement of suspicion, indeed Police Scotland's "Stop and Search Operational Toolkit" (“Toolkit”), which provides non-binding operational guidance to officers, explicitly states that non-statutory powers can be deployed when a person "is not acting suspiciously, nor is there any intelligence to suggest that the person is in possession of anything illegal", 47

\section{COMPATIBILITY WITH THE ECHR}

Turning now to the compatibility of the powers, the main issue in relation to all categories is whether they are prescribed by law. ${ }^{48}$ This concern is particularly acute in relation to suspicionless statutory and the non-statutory powers. The test of reasonable suspicion is relevant to the suspicion-based statutory powers and consent to non-statutory powers. There are additional issues, particularly in relation to suspicion-based powers, which are better viewed as bad practice rather than breaches of the ECHR, which shall also be highlighted.

As the two ECtHR cases on stop and search, Gillan v United Kingdom and Colon v the Netherlands, concern suspicionless statutory powers, that category will be analysed first

Department [2014] EWHC 255 (Admin), [2014] 1 WLR 3140. See further: D Anderson, The Terrorism Acts in 2013 (2014) paras 4.11-4.23. See also Beghal v DPP [2015] UKSC 49 on questioning under sch 7.

${ }^{46}$ Although subject to reasonable suspicion, the powers to stop and search under the Modern Slavery Act 2015 sch 2, paras 2-3 and under the Counter-Terrorism Act 2015 sch 1, para 2 bear more resemblance to sch 7 for these reasons.

${ }^{47}$ Toolkit (2014) 8.

${ }^{48}$ Note the term "in accordance with the law" is used interchangeably with "prescribed by law". There is no difference between these expressions, which are translations of the same French expression "prévues par la loi" (Sunday Times para [48]). 
in order to determine the approach taken by the court. ${ }^{49}$ The subsequent sections will assess whether the statutory and non-statutory powers breach the ECHR.

\section{(1) Suspicionless statutory powers}

In Gillan, the power conferred by section 44 of the Terrorism Act 2000 ("the 2000 Act") (the predecessor to the currently applicable section 47A, which replaced it) was held not to be prescribed by law. Less than two years later, "preventive searches" (broadly analogous to the searches authorised under section 60 of the Criminal Justice and Public Order Act 1994) were held in Colon to be prescribed by Dutch law and justifiably to infringe Article 8, although it is notable that the complaint was restricted to whether effective judicial remedies were available. The respective powers conferred by the British and Dutch legislation will be briefly outlined, before assessing the contrasting outcomes.

Under section 44, a senior police officer could authorise the use of the power if he considered doing so "expedient for the prevention of terrorism". ${ }^{50}$ The Secretary of State had to confirm the authorisation, which could extend across the force area and last for up to twenty-eight days. ${ }^{51}$ Once authorised, a uniformed officer could stop and search any person, vehicle or passenger therein within the authorised area for articles of a kind that could be used in connection with terrorism. ${ }^{52}$

In relation to "preventive searches" under Dutch law, a Local Council could, under the Municipalities Act section 151b, pass a bye-law enabling the Burgomaster (Mayor) of a municipality to designate an area of the city as a "security risk area" if there was a "public order disturbance caused by the presence of weapons" or fear of this occurring. ${ }^{53}$ Colon concerned the Burgomaster of Amsterdam, who after consultation with the head of the regional police and the public prosecutor, had made designations for successive six and (later) twelve month periods. ${ }^{54}$ Thereafter, the public prosecutor was permitted to designate a

${ }^{49}$ Colon $v$ the Netherlands (2012) 55 EHRR SE5; Gillan v United Kingdom (2010) 50 EHRR 45.

${ }^{50}$ Terrorism Act $2000 \mathrm{~s} 44(3)$. Note that ss 44-47 were repealed under the Protection of Freedoms Act 2012 s 59.

512000 Act s 46(2).

522000 Act s 45(1)(a).

${ }^{53}$ Colon para [2].

${ }^{54}$ Colon paras [3], [5] [14]-[16]. There was one twenty-four month designation which was later reduced to twelve months [16]. 
twelve hour period in which the police could conduct suspicionless stop and search on persons or vehicles, the object of the search being offensive weapons.

Refusal to submit to a search, or the obstruction of an officer in the exercise of either power, was a criminal offence punishable by up to six months' imprisonment and/or a level 5 fine (in relation to section 44 of the $2000 \mathrm{Act}$ ) ${ }^{55}$ or up to three months' imprisonment and/or a fine (in relation to preventive searches). ${ }^{56}$

The Dutch authorisations were more narrowly tailored, owing to the system of double-designations. The ECtHR also highlighted the greater democratic control evident in Colon. ${ }^{57}$ Presumably this referred to the involvement of the Local Council and the greater ease with which the bye-law could be changed, as well as to the role of the public prosecutor. However, the deployment of the power in both cases was remarkably similar, with virtually unfettered discretion afforded to officers. The key difference therefore appears to have been the practice. In Gillan the various accountability structures over the authorisation process had demonstrably failed by the time of the case. Despite the nominal geographical and temporal limits, section 44 of the 2000 Act was in force across the entire Metropolitan Police Service area continuously from February 2001 until July 2009. No authorisations were refused by the Secretary of State. ${ }^{58}$ However, in Colon the ECtHR did not inquire into whether a similar "rubber-stamping" occurred in relation to preventive searches: the area in question had been under continuous designation from 2002 to 2009, which suggests the accountability systems may not have been particularly rigorous, although it was not stated how many "subdesignations" were imposed by the public prosecutor. Similarly, while the ECtHR noted in Gillan the disproportionate impact on "black" and ethnic minority communities, and that there were no terrorism related arrests subsequent to a search under the 2000 Act section 44, there was no discussion in Colon of these issues in relation to preventive searches. ${ }^{59}$ Crucially, however, in Colon the Dutch government relied on two independent studies which showed that the use of weapons had decreased in the security risk areas and increased in relation to other areas. ${ }^{60}$ There was no equivalent "proof" of effectiveness proffered in Gillan.

\footnotetext{
552000 Act s 47.

${ }^{56}$ Netherlands Criminal Code art 184.

${ }^{57}$ Colon para [67].

${ }^{58}$ Gillan para [80].

${ }^{59}$ Gillan paras [84]-[85].

${ }^{60}$ COT Institute for Safety and Crisis Management, Evaluatie Preventief Fouilleren in Amsterdam: opbrengsten, wapenincidenten en hot spots (2007); COT Institute for Safety and
} 
Three key points can be gleaned from these cases. First, routine stops and searches will engage Article 8 of the ECHR. Second, the greater the discretion in relation to whom to select to stop and search (what Ip terms "back-end" discretion ${ }^{61}$ ), the greater the oversight that will be required, for example through a system of authorisation. As the oversight itself involves discretion (what Ip terms "front-end" discretion), this must also be sufficiently controlled. Third, although the effectiveness of the scheme should not speak to whether the power is prescribed by law or not, being relevant to whether the infringement is justifiable, it appears from Colon to carry significant weight.

In light of Colon and Gillan, it may be asked: is the power conferred by section 47A of the 2000 Act prescribed by law? The section is an improvement on its predecessor. The authorisation process has been tightened by raising the trigger from "expedient" to "necessary", with the added requirement that the authorising officer reasonably suspects that an act of terrorism will take place. ${ }^{62}$ The accompanying Code of Practice, which in a departure from section 44 of the 2000 Act applies to the authorisation as well as deployment of the power, states that authorisations cannot be solely aimed at public reassurance, deterrence, or intelligence-gathering. ${ }^{63}$ The maximum temporal limit has been reduced and a new requirement added that the geographical and temporal limits be no more than necessary to prevent the act of terrorism. ${ }^{64}$ There is nominally a prohibition on "rolling" authorisations, although this is undermined by the contemplation of successive authorisations in the Code. ${ }^{65}$ In terms of back-end discretion, little has changed. While the object of the search has been altered, it remains exceptionally broad, largely because of the breadth of the definition of

Crisis Management, Evaluatie Preventief Fouilleren in Amsterdam: de stand van zaken (2006).

${ }^{61} \mathrm{~J}$ Ip, "The reform of counterterrorism stop and search after Gillan v United Kingdom" (2013) 13 HRLR 729 at 731.

${ }^{62} \mathrm{~S} 47 \mathrm{~A}(1)$.

${ }^{63}$ Home Office, Code of Practice (England, Wales And Scotland) for The Exercise of Stop and Search Powers Under Sections 43 and 43 a of the Terrorism Act 2000, and the Authorisation and Exercise of Stop and Search Powers Relating To Section 47a of, and Schedule 6b to, the Terrorism Act 2000 (2012) (Hereafter "Code Of Practice Terrorism Act 2000") para 4.1.6. This is significant given that the primary objectives of s 44 for the police were deterrence and disruption. See further G Lennon, "Precautionary Tales: Suspicionless counter-terrorist stop and search" (2015) 15 CCJ 44.

${ }^{64}$ Home Office "Code of Practice Terrorism Act 2000" paras 4.2.3, 4.2.5.

${ }^{65}$ Ibid, para 4.3. 
terrorism, ${ }^{66}$ and a "clear risk of arbitrariness" remains ${ }^{67}$ Much will therefore depend on the actual use of the power, especially as the law is sufficiently broad and vague to permit a varied practice. This has been restrained in the extreme: notwithstanding events such as the London Olympics and the Glasgow Commonwealth Games, there has been no authorisation in Great Britain to date. ${ }^{68}$ The sole authorisation occurred in Northern Ireland in the summer of $2013 .{ }^{69}$ It appears therefore that the police are adhering to the spirit and not just the letter of the law. Notably, it seems probable that a degree of imminence between the suspected act of terrorism and the necessity of the authorisation has been implied. Given this approach, the power seems likely to be one prescribed by law. ${ }^{70}$

What of section 60 of the 1994 Act? Its compatibility with the ECHR was recently considered by the Supreme Court in Roberts $v$ Commissioner of Police of the Metropolis, which, affirming the decisions of the Court of Appeal and the Divisional Court, unanimously dismissed the appeal. ${ }^{71}$ The Court accepted that suspicionless stop and search will constitute an interference with Article $8 .^{72}$ As in Gillan, the power clearly has a basis in law, ${ }^{73}$ the issue being whether there are sufficient safeguards to prevent its arbitrary use.

The Court outlined the relevant case-law, discussing Gillan, Colon and Beghal, which concerned stops under Schedule 7 of the 2000 Act, but did not explain how these cases applied to or could be distinguished from the case in hand. ${ }^{74}$ The concluding discussion asserted the benefits of suspicionless powers, notwithstanding the inherent risk that they will be used in an arbitrary or discriminatory manner. ${ }^{75}$ The potential for discrimination was primarily addressed by noting that it is unlawful for officers to act in a discriminatory manner under Code A, the HRA section 6 and the Equality Act $2000 .{ }^{76}$ This circular reasoning - that the police will not act unlawfully because it would be unlawful to do so - does not evidence

${ }^{66} 2000$ Act s 1. See, e.g., Anderson, Terrorism Acts (n 45) paras 4.20-4.21, 10.6-10.18; C Walker, "The legal definition of 'terrorism' in United Kingdom law and beyond" (2007) PL 331.

${ }^{67}$ Gillan para [85].

${ }^{68}$ D Anderson, The Terrorism Acts in 2014 (2015); Anderson, Terrorism Acts ( $\mathrm{n} 46$ ).

${ }^{69}$ Anderson, Terrorism Acts (n 45) paras 6.8-6.11.

${ }^{70}$ Cf E Cape, "The counter-terrorism provisions of the Protection of Freedoms Act 2012: Preventing misuse or a case of smoke and mirrors?" (2013) 5 CrimLR 385 at 397-398.

${ }^{71}$ [2015] UKSC 79, [2014] 1 WLR 3299, [2014] EWCA Civ 69.

${ }^{72}$ Roberts para [3].

${ }^{73}$ Discussed further below in relation to the non-statutory power.

${ }^{74}$ Paras [15]-[26].

75 Para [41].

${ }^{76}$ Paras [34]-[37]; [42]. 
sufficient safeguards against the arbitrary exercise of section 60 of the 1994 Act. Notably, all these provisions applied equally to section 44 yet the ECtHR explicitly voiced concerns over its impact on "black" and ethnic minority communities. ${ }^{77}$ The Supreme Court concluded by highlighting features of the authorisation and deployment processes that "make it possible to judge whether the action was 'necessary in a democratic society...for the prevention of disorder or crime $"{ }^{78}$ While adequate review processes are a necessary element of legality, they cannot of themselves cure a power that is so broad as to risk arbitrariness. Moreover, the question of whether the interference is proportionate and therefore justifiable is secondary to the issue of whether the power is prescribed by law. The judgment fails to provide a clear exposition of the how the putative safeguards minimise the potential for the arbitrary exercise of the power.

The front-end discretion afforded to officers under section 60 of the 1994 Act is more circumscribed than section 44 of the 2000 Act was. As Kay, LJ noted in the Court of Appeal, the criteria for authorisation requires "that the authorising officer reasonably believes specified things relating to serious violence, dangerous instruments and offensive weapons" and this "incorporates an objective criterion which is more readily susceptible to judicial review" ${ }^{79}$ In addition the temporal and geographical limits are narrower.

However, the back-end discretion, where the risk of arbitrary treatment is most acute, is largely equivalent. Section 60 has a narrower object for the search but, as the ECtHR stated in Gillan, this does little to fetter discretion as officers are not required to suspect the person is in possession of the object. ${ }^{80}$ Although the Supreme Court noted that the ECtHR in Gillan was "[a]bove all...concerned at the breadth of the discretion given to the individual police officer", the judgment fails to explain how section 60 substantially differs in the discretion it affords individual officers. ${ }^{81}$

While a comparison with Gillan suggests that section 60 of the 1994 Act would not be prescribed by law, preventive searches muddy the waters, affording the same back-end discretion to officers with a virtually identical object of the search as section 60. Comparing the three powers, the back-end discretion is the virtually identical for each. The front-end discretion for section 60 is slightly more circumscribed than for section 44 but lacks any of

\footnotetext{
${ }_{77}$ Gillan para [85].

78 Paras [44]-[47].

${ }^{79}$ Roberts (CA) para [23].

${ }^{80}$ Gillan para [83].

${ }^{81}$ Roberts (SC) para [20].
} 
the additional democratic features seen in Colon or the system of double designation. While judicial review has more to grasp in relation to section 60 than with section 44 this is only in relation to the authorisation process; in relation to the back-end discretion, any review, judicial or otherwise, faces the same challenges as it would have under section 44. Colon suggests that the actual practice could be the trump card.

The Supreme Court in Roberts asserted that there are 'great benefits to the public' from suspicionless powers such as that under section 60 in relation to deterrence and increased detection, referring to the judgment of Moses, LJ in the Divisional Court. ${ }^{82}$ However, the benefits must be balanced against any detriment impact and account must be taken of the effectiveness of the power. Moses, LJ noted there were 4,273 arrests in 2008-09, compared with the total absence of arrests under section 44 of the 2000 Act. ${ }^{83}$ However, Moses, LJ fails to put this in context. The 4,273 arrests accounted for $2.8 \%$ of the total stops conducted under section 60 that year. Moreover, only 533 arrests - or $0.3 \%$ of the total were in anticipation of violence $.^{84} 2008 / 09$ represented the peak usage of the power, with 149,955 stops and searches conducted. In 2010, when Ms Roberts was stopped, the number of stops was starting to decline but remained exceptionally high (118,112 in 2009/10 and 60,145 in 2010/11). ${ }^{85}$ This peak usage coincided with the greatest degree of disproportionality - only $40 \%$ of stops were of white persons in $2009 / 10$, falling to $31 \%$ in 2010/11 before starting to slowing rise again. ${ }^{86}$ At face value, these statistics evidence greater levels of disproportionality than section 44 had. ${ }^{87}$ The practice seems to have turned a corner - prompted, presumably, in part by Roberts. The latest figures for 2011/12 show the number of stops has collapsed to 46,871, and it seems likely that, as a result of the Best Use of Stop and Search Scheme (BUSS) discussed below, this trajectory will continue. ${ }^{88}$ Nonetheless, the

\footnotetext{
${ }^{82}$ Para [41].

${ }^{83}$ Roberts (QB) para [40].

${ }^{84}$ Ministry of Justice, Statistics on race and the criminal justice system 2010 (2012).

${ }^{85}$ Ibid and Ministry of Justice Statistics on race and the criminal justice system (2013).

${ }^{86}$ Ministry of Justice, Statistics (2013) 44. According to the 2011 census, "white" people constituted $86 \%$ of the English and Welsh populations (ONS "Ethnicity and National Identity in England and Wales 2011": see http://www.ons.gov.uk/ons/rel/census/2011-census/keystatistics-for-local-authorities-in-england-and-wales/rpt-ethnicity.html.

${ }^{87}$ See, e.g., M Shiner, Report on the use of section 60 of the Criminal Justice and Public Order Act 1994 by the police (February 2012) and Report for Bhatt Murphy Solicitors (available at:

http://www.stopwatch.org/uploads/documents/Shiner_expertwitnessstatement_s60.pdf). ${ }^{88}$ Ministry of Justice, Statistics (2013). The Metropolitan Police Service (MPS), the largest user of s 60 , have reduced the authorisations by $97 \%$ and the overall number of s 60 stops by
} 
practice at the time Roberts was stopped and the effectiveness of the power more generally merited consideration by the Court.

It is not possible to say with any certainty what the outcome of an appeal of Roberts to the ECtHR would be. But the combination of the changing practice, the closer similarity of the power to Colon than Gillan, and the apparent turning of the tide evident in cases like Austin v United Kingdom ${ }^{89}$ and Colon, suggest that the power would be held to be prescribed by law..$^{90}$ Certainly, current practice under BUSS seems likely to be so.

However, this conclusion does not necessarily apply to section 60 of the 1994 Act as practiced in Scotland, as there are a number of differences between the jurisdictions. First, there is no equivalent to PACE Code A. Police Scotland's "Toolkit", discussed further below, lacks the requisite granularity and is not binding upon officers. Notwithstanding the preceding criticism of Code A's relevance to whether the power is prescribed by law, it has been afforded a degree of importance by the domestic courts. Second, the English and Welsh forces have accepted a number of additional - and voluntary - restrictions upon the power under the BUSS. The trigger has been raised to "necessary" and the maximum time limit reduced to 15 hours, extendable by a further $24 .^{91}$ There is also a requirement that all authorisations are communicated to the public afterwards and, where practicable, in advance. ${ }^{92}$ Third, practice diverges radically between Scotland and the rest of Britain: while, owing to the total inadequacy of the Scottish data, it is impossible to state with any certainty, it appears that section 60 is largely unused (this is discussed further in the next section). This makes sense, given the availability of non-statutory stop and search. Were non-statutory stop and search to be prohibited, as suggested in an amendment to the Criminal Justice (Scotland) Bill, ${ }^{93}$ this would raise the possibility of a rapid rise in the use of section 60 to bridge the gap between areas where non-statutory powers were previously used when it was suspected that offensive weapons were being carried.

99\%: see http://content.met.police.uk/Article/How-we-use-stop-andsearch/1400022268811/1400022268811. Although cf F Hamilton, "Knife crime on increase as stop and search falls" The Times, 22 June 2015, pp 1-2, which stated that the MPS Commissioner was considering increasing stop and search.

${ }^{89}$ (2012) 55 EHRR 14. See further G Lennon, "The purpose of the right to liberty under the ECHR, Article 5" (2012) 3 Web JCLI.

${ }^{90}$ See also M Zander, "Section 60 stop and search IS lawful" (2014) 178 CL\&JW 87.

${ }^{91}$ Home Office, Best use of stop and search scheme (2014).

${ }^{92}$ Ibid.

${ }^{93}$ Proposed amendment 49 (McInnes). 
To ensure that the power conferred by section 60 of the 1994 Act is prescribed by law in Scotland, a number of changes should be made. The changes under BUSS are positive and should be adopted, ideally through statutory amendment rather than on a voluntary basis. As argued below, additional regulation along the lines of Code $\mathrm{A}$ is desperately needed in relation to all areas of stop and search, as are heightened post-hoc systems of accountability. Specifically in relation to section 60 , data should be published on the number of authorisations and stops conducted, and these should be linked to the locality for which they are authorised. There may be grounds for some anonymization when publishing the data, however the full data set should be provided to the relevant oversight bodies (such as the Scottish Police Authority and the HMICS). The use of suspicionless statutory powers in relation to demonstrations has proven contentious at times in England and Wales, impacting both directly and through the chilling effect upon the rights to free assembly and speech, and guidance on the appropriate use of the power at protests should be issued. ${ }^{94}$

Using the power to plug the holes which the non-statutory power would traditionally have dealt with, whether with fifteen or twenty-four hour maximums, would necessitate very frequent, if not near-rolling, authorisations in some localities. In essence, such an approach would largely undermine the apparent value of the authorisation process. Even with the proposed changes, such practice is reminiscent of the approach of the MPS in relation to section 44 of the 2000 Act. An ineffectual authorisation process that appears to be merely rubber-stamping, and which goes hand-in-hand with an unfettered power of deployment, is likely to fail the standards required by the ECHR.

A more radical option which might permit broader use of the power would be to adapt from the Dutch their system of double-designations. The Procurator Fiscal would be an obvious choice to mirror the role of the Public Prosecutor, although there are, of course, a number of differences in their roles. Another option would be to require judicial approval. Following Colon, the added layer of accountability may possibly be sufficient to permit more extensive use of the power, particularly if evidence showed it is effective, although a near constant sub-designation is unlikely to be prescribed by law even with judicial oversight.

\footnotetext{
${ }^{94}$ See, e.g., $R$ (Laporte) $v$ Chief Constable of Gloustershire Constabulary [2007] 2 AC 105, [2006] UKHL 55; Joint Committee on Human Rights, Demonstrating Respect for Rights? A human rights approach to policing protest (HL 47-I, HC 320-I: 2009) -especially paras 8695 (in relation to s 44); K Reid, "Letting down the drawbridge: restoration of the right to protest at Parliament" (2013) 1 Law, Crime and History 16 at 46.
} 


\section{(2) Suspicion-based statutory powers}

There are two, interlinked, issues with this category of powers: whether the main safeguard of reasonable suspicion is adhered to by the police and whether there are sufficient additional safeguards to prevent the arbitrary deployment of the powers. The latter may raise concerns about whether the powers are prescribed by law, but as detailed below, the arguments are relatively weak and are better considered as bad practice rather than incompatibility with the ECHR. Deploying one of these powers without reasonable suspicion would be illegal and the officer may be committing actionable wrongs, in relation to assault and wrongful detention. Evidence secured through the search may also be deemed inadmissible, although the court can excuse irregularity in the method by which the evidence was obtained. ${ }^{95}$

The "principal safeguard" over statutory stop and search powers is the trigger of reasonable suspicion. ${ }^{96}$ The test for reasonable suspicion was set out in O'Hara $v$ Chief Constable of the RUC, ${ }^{97}$ and applied most recently in Scotland in relation to stop and search in McAughey v HM Advocate. ${ }^{98}$ O'Hara provides a hybrid test:

In part it is a subjective test, because [the officer] must have formed a genuine suspicion in his own mind ... In part also it is an objective one, because there must also be reasonable grounds for the suspicion which he has formed. ${ }^{99}$

The suspicion must be in the officer's mind at the time the power is deployed, and must be based on facts known at that time. ${ }^{100}$ Suspicion may be based on evidence that would be inadmissible in court. ${ }^{101}$ As reaffirmed in recent High Court judgments, instructions from a superior cannot, without more, constitute reasonable suspicion, as the officer conducting the search will have no objective grounds upon which to base a suspicion. ${ }^{102}$

\footnotetext{
${ }^{95}$ Lawrie v Muir 1950 JC 19. See further P Duff, "Admissibility of improperly obtained physical evidence in the Scottish criminal trail” (2004) 8(2) EdinLR 152.

${ }^{96} \mathrm{RCCP}$ (n 10) para 3.25.

97 [1997] AC 286, approved in O'Hara v United Kingdom (2002) 34 EHRR 32. For further discussion of the discretion at play in relation to reasonable suspicion and arrest, see $\mathrm{C}$ Ryan and K Williams, "Police Discretion" [1986] PL 285.

982014 SCL, [2013] HCJAC 163.

${ }^{99}$ O'Hara at 298 per Lord Hope.

${ }^{100}$ HMA v B 2013 SCL 592, [2013] HCJ 71.

${ }^{101}$ Shaaban Bin Hussien v Chong Fook Kam [1970] AC 942.

${ }^{102}$ HMA v B; McAughey v HMA [2013] HCJAC 163, 2014 SCCR 11. See also Raissi v Commissioner of Police of the Metropolis [2009] QB 564, [2008] EWCA Civ 1237.
} 
The "Toolkit" defines reasonable suspicion as suspicion

that is backed by a reason capable of articulation and is something more than a hunch or a whim ... The officer has to have intelligence or information supporting the reason for the search such as the person slurring their words or that the person is showing behaviour that is leading to the officer's suspicion. ${ }^{103}$

This fails clearly to emphasise the need for officers to have formed the suspicion themselves. There is also no explicit linkage between the suspicion and the object of the search. Suspecting someone of some criminal behaviour is not sufficient as grounds for a statutory stop and search: the suspicion must relate to the object of that particular power. Contrast PACE Code A para 2.2, where the test for reasonable suspicion requires:

Firstly, the officer must have formed a genuine suspicion in their own mind that they will find the object for which the search power being exercised allows them to search...; and (ii) Secondly, the suspicion that the object will be found must be reasonable. This means that there must be an objective basis for that suspicion based on facts, information and/or intelligence which are relevant to the likelihood that the object in question will be found, so that a reasonable person would be entitled to reach the same conclusion based on the same facts and information and/or intelligence."104

The "Toolkit" goes on to list a number of factors: intelligence on the location, suspect, friends, families, or associates; previous convictions or knowledge of subject; PNC/CHS warning signals; the suspect's course of conduct, demeanour, or explanation as to why they are at that location; the suspect's clothing, possessions, or - where possession of alcohol is a factor - age; and recent incidents (responding to a gang fight where weapons were mentioned). ${ }^{105}$ While these may all be relevant, the majority must be coupled with additional information in order to provide adequate grounds for suspicion, and the Toolkit should be

\footnotetext{
103 At 6.

${ }^{104}$ Para 2.2 (emphasis in the original).

${ }^{105}$ At 6.
} 
explicit on this point. For example, the mere fact of a person's associations or previous convictions cannot provide reasonable suspicion. ${ }^{106}$

Overall, the "Toolkit's" guidance is at best ambiguous and at worst misleading. Key aspects of the legal test are not made clear and the confusing list of factors may encourage officers to rely on irrelevant or insufficient grounds.

The second, related, issue concerns the regulation of officer conduct during and after the search. As the Royal Commission on Criminal Procedure commented in 1981, when assessing stop and search powers in England and Wales, there is a "risk that the criterion [for reasonable suspicion] could be loosely interpreted". The Commission concluded that "the notification of the reason for the search to the person who has been stopped, the recording of searches by officers, and the monitoring of the records by supervising officers would be the most effective and practical ways of reducing the risk". ${ }^{107}$ It also recommended that all officers provide the person stopped with the officer's name and number. ${ }^{108}$ Currently, Scottish practice fails to meet these minimum standards. An exceptionally light-touch approach to regulating officer conduct is taken, with inconsistency in the rules that exist.

Requiring an officer to inform the person stopped of the grounds for the stop and search provides a check upon the arbitrary exercise of the power, as well as being important in ensuring the person's satisfaction with the encounter. ${ }^{109}$ Where found in Scottish legislation, the requirement to provide grounds only applies when the officer moves to search the person, not at the initial point of stopping them. It is required for some powers but not others, with the division being largely unintelligible. For example, an officer is required to inform a person stopped and searched on suspicion of being in possession of or carrying an offensive weapon in a public place of the reason why the person is being detained for a search, but not if the search takes place on school premises. ${ }^{110}$ This is not a blanket exception for schools: a person stopped and searched on suspicion of being in possession of or carrying an article with a blade or point, whether in public or on school premises, must be informed of

\footnotetext{
${ }^{106}$ McArdle v Egan (1934) 150 LT 412 (prior convictions); Reynolds v Commissioner of Police for the Metropolis [1982] Crim LR 600 (association). See, further, Ryan and Williams (n 97).

${ }^{107}$ RCCP (n 10) para 3.25.

108 Ibid para 3.22.

${ }^{109}$ N Bland, J Miller, and P Quinton, Upping the PACE? An evaluation of the recommendations of the Stephen Lawrence Inquiry on stops and searches (2000); RCCP (n 10) para 3.25 .

${ }^{110}$ Criminal Law (Consolidation) (Scotland) Act 1995 ss 48, 49B.
} 
the reason for the search. ${ }^{111}$ Other examples abound. If there is logic here, it is beyond the ability of this author to discern it.

There are, however, some predictable patterns. Powers enabled by UK statutes do not require officers to inform the person of the reason for the search. This is presumably because it is required under section 2 of PACE 1984 in England, Wales, and Northern Ireland, with additional requirements found in section 3 and in Code A. Stops and searches conducted anywhere in the UK under the Terrorism Act 2000 must adhere to the relevant Code. ${ }^{112}$

Scottish police officers do not need to identify themselves if they are in uniform. By contrast, in the rest of the UK the police are obliged to provide their name and the name of their station. ${ }^{113}$ This is rigorously enforced by the courts, when challenged. For example, in $R$ $v$ Christopher Bristol, the Court of Appeal, quashing the appellant's conviction, rejected the police officer's assertion that he could not provide his name and station before applying mandibular pressure to prevent a suspected wrap of drugs being swallowed. ${ }^{114}$ An officer's name - or warrant number if appropriate - and station is important information in order for a person to make a complaint or to query conduct that has taken place.

Again in contrast to the position in the rest of the UK, Scottish police do not need to issue any form of written record to the person stopped. The issuing of these "stop forms" was instituted in the rest of the UK following the Stephen Lawrence Inquiry, and a form must be given to all persons stopped and searched at the time, unless there are exceptional circumstances. ${ }^{115}$ These stop forms were broadly welcomed by the public in the pilot study, who perceived the key benefits as having information on "the reason for the stop; the name of the officer in case they wanted to complain; and the explanation of police powers and public rights". ${ }^{116}$ In a recent pilot study in Fife, advice slips were issued to all persons stopped and searched. Although the study recommended including additional details, it broadly welcomed

\footnotetext{
${ }^{111}$ Ibid s 50 .

112 Terrorism Act 2000 s 47AE; Home Office, "Code of Practice Terrorism Act 2000”. This anomaly is not limited to stop and search: e.g.. prior to Cadder v HM Advocate 2010 SCL 1265, [2010] UKSC 43, anyone arrested under the Terrorism Act $2000 \mathrm{~s} 41$ had a right to access to a lawyer, and to various other safeguards found in PACE Code $\mathrm{H}$.

113 PACE s 2(2)-(3).

114 (2008) 172 JP 161, [2007] EWCA Crim 3214. See also R (Michaels) v Highbury Corner Magistrates' Court [2010] CrimLR 506, [2009] EWHC 2928 (Admin) (applies even when officer and suspect are known to each other).

${ }^{115}$ PACE Code A paras 4.1, 4.2B.

${ }^{116}$ Bland, Miller and Quinton (n 109) x.
} 
these trials as "a positive development for stop and search practice as they help to increase its transparency". 117

While the current focus on stop and search has led to a number of ad hoc forms of scrutiny, ${ }^{118}$ all are exceptional one-offs. ${ }^{119}$ A systematic and routine review structure is urgently needed. A major impediment to effective post-hoc scrutiny in Scotland is the lack of rigorous recording requirements, coupled with the absence, until 2014, of published data. ${ }^{120}$ While bare statistics will neither prove nor disprove bad practice, they are a vital cog in the accountability wheel and can aid in identifying areas of concern that merit further investigation. Routine post-hoc scrutiny is particularly important, as research shows that individuals tend not to make formal complaints against the police, even when dissatisfied. ${ }^{121}$ Of course, such data must be relevant and accurate. HMICS have stated that they "do not have confidence in the stop and search data currently held by Police Scotland" and that the stop and search database requires substantial improvements to be fit for purpose. ${ }^{122}$

Officers are currently obliged to record: their name; the date, location, and time of the stop and search; whether it is statutory or non-statutory; whether any items were detected; and, if so, what they were. In addition, they may record the stopped person's details, for instance date of birth. While this is fine as far as it goes, there is insufficient detail for effective accountability. ${ }^{123}$ It is imperative that the grounds for reasonable suspicion be recorded so that the major safeguard over the suspicion-based statutory powers can be evaluated. ${ }^{124}$ The legislative power used should also be recorded. This would feed into the

${ }^{117}$ O’Neill, Aston and Krause (n 21) para 4.6.2.

${ }^{118}$ See nn (9) and (Error! Bookmark not defined.).

${ }^{119}$ Cf RCCP (n 10) which recommended that stop and search data be included in annual reports in order to enable Police Authority scrutiny, and that the HMIC examine the powers in their annual force reports (para 3.2.6). The HMIC's annual PEEL Inspections include a question on stop and search, available at https://www.justiceinspectorates.gov.uk/hmic/ourwork/peel-assessments/peel-2015-questions/.

${ }^{120}$ All prior data sets are from Freedom of Information requests (see further Murray (n 6)).

${ }^{121}$ G Smith, "Why don't more people complain against the police?" (2009) 6(3) EJCrim 249.

${ }^{122}$ HMICS (n 9) 5. On the importance of accurate data, see further Sir M Bichard, The Bichard Inquiry Report (HL 2008-09, 18-I). While beyond the scope of this article, there must also be adequate structures for securing and retaining data. Police Scotland "lost" 20,087 stop and search records due to human error (see further HMICS 58-63).

${ }^{123}$ See further HMICS (n 9).

${ }^{124}$ For instance, an analysis of the grounds for reasonable suspicion formed a key part of HMIC's analysis in "Stop and search powers: Are the police using them effectively and fairly?" (2013) and (2015). 
assessment of the relevant grounds, permit the identification of policing trends, and may provide an indication of whether the powers are being used appropriately. For example, if a high proportion of items seized under a particular power were not the object of the search (e.g. drugs found in an offensive weapons search), this could indicate that officers are not employing the appropriate legislation or are acting without reasonable suspicion; further evaluation would then be merited. The outcome of the search should also be recorded. At the least, whether the person was detained or arrested should be noted, although a broader range of outcomes would be preferable as it would permit a more nuanced assessment of the powers. For example, under BUSS, officers are required to record one of seven outcomes: arrest, summons, caution, Khat or cannabis warning, penalty notice, community resolution, or no further action disposal. ${ }^{125}$

It is clear that significant changes are needed to the regulation of officer conduct and recording requirements. These, and an improved explanation of reasonable suspicion, should be instituted through a statutory code along the lines of PACE Code A, which would be binding upon officers and the breach of which would be admissible as evidence, though not of itself constituting either a civil or criminal wrong. ${ }^{126}$

While the current approach falls well short of best practice, is it compatible with the ECHR? The absence of a systematic review structure and the difficulties in enforcing one, given the inadequate data recording and the absence of stop forms, heighten the risk of the arbitrary deployment of the powers. This, alongside the lack of a requirement for officers to provide their name or warrant number, may also complicate attempts to seek redress in the courts. However, it is doubtful that these issues, even in conjunction with the absence of a detailed code of practice, would lead the ECtHR to conclude that the powers were not prescribed by law. The powers are not unfettered: they are bounded by the requirement of reasonable suspicion in relation to the object of the search. While it is arguable how effective this is in practice, there are routes for redress through the domestic courts if a search is conducted without reasonable suspicion, notwithstanding the inevitable difficulties of proving such a claim. Given that preventive searches were prescribed by law, it seems highly improbable that suspicion-based statutory ones would fall at that hurdle.

\footnotetext{
125 Para 1.3.

${ }^{126}$ See PACE 1984 s 67(10) and (11).
} 


\section{(3) Non-statutory powers}

Turning finally to the most problematic category, non-statutory stops and searches, the major issue is whether the power is ECHR compliant.

In the absence of a statutory power, it is the consent of the stopped person that ensures the police have not committed one or more actionable wrongs (such as assault). While the question of consent depends on individual circumstances, current practice raises concerns in relation to whether consent was informed and voluntary, and whether all persons stopped had capacity to consent.

Following Brown $v$ Glen, police are not required to inform the person that consent to the stop and search may be withheld. ${ }^{127}$ Lord Sutherland reasoned that:

Where ... the police are making general enquiries and the person with whom they are dealing has not reached the stage where he could be described as a suspect, except in the most general and nebulous sense, the police are not obliged to caution the person as to his answers to questions and there appears to us to be no logical reason why they should be obliged to issue any caution to accompany a request for a search to be carried out when it must be perfectly obvious that the answer to that request may be either yes or no. ${ }^{128}$

The analogy with stop and question is misplaced. The public nature of a search and the accompanying potential of "an element of humiliation and embarrassment" was singled out by the ECtHR as "compounding the seriousness of the interference" with the right to a private life under Article 8 of the ECHR. ${ }^{129}$ Whether the search is of the person's pockets, or a full "pat-down", perhaps after outer clothing has been removed, this is necessarily more intrusive than asking someone a question.

More generally, should the police be required to inform the person that consent may be withheld? International approaches vary on whether consent is nugatory in the absence of

1271998 JC 4.

${ }^{128}$ Ibid 6. See also Freeburn v HM Advocate 2013 SCL 47, [2012] HCJAC 135.

${ }^{129}$ Gillan [63]. The potential for embarrassment from a public search was also acknowledged by Lord Hope in R (Gillan) v Commissioner of Police of the Metropolis [2006] UKHL 12 [48] and Kay LJ in Roberts $v$ Commissioner of Police of the Metropolis [2014] 1 WLR 3299, [2014] EWCA Civ 69, at [15]. 
being informed of the right to refuse. While Canada ${ }^{130}$ and New Zealand ${ }^{131}$ require it as a prerequisite to consent, neither Australia ${ }^{132}$ nor the USA do. ${ }^{133}$ The approach of the former jurisdictions should be preferred for two reasons. First, consent must be informed. As $\mathrm{Mr}$ Justice Marshall stated in his dissent in the leading US case:

I am at a loss to understand why consent "cannot be taken literally to mean a 'knowing' choice"... In fact, I have difficulty in comprehending how a decision made without knowledge of available alternatives can be treated as a choice at all. ${ }^{134}$

The second reason is the authoritative character of the police. The Canadian Supreme Court held that consent without a clear indication of the right to refuse is invalid "[b]ecause of the intimidating nature of police action and uncertainty as to the extent of police powers, compliance in such circumstances cannot be regarded as voluntary in any meaningful sense." 135 As noted by the New Zealand High Court, "while consent may include acquiescence, it must be a genuine consent and not a mere acquiescence in what a person believes to be another's lawful right". ${ }^{136}$ Research conducted in the late 1980s in England when non-statutory stops and searches were permitted - supports the view that the authoritative character of the police impacts upon people's choice to consent, finding that the combination of the lack of knowledge and power on the part of the person stopped, the unwillingness of police to give information, and their tendency to "bamboozle" the suspect meant that "cconsent' ... frequently consists of acquiescence based on ignorance" against a background of "contextual irrelevance of rights and legal provisions". ${ }^{137}$ This, and other research, also reveals Lord Sutherland's statement that "it must be perfectly obvious that the

\footnotetext{
${ }^{130}$ Dedman v R 198446 CR (3d) 193.

${ }^{131}$ Meates v Attorney-General [1981] 2 NZLR 335.

${ }^{132}$ DPP v Leonard [2001] NSWSC 797.
}

${ }^{133}$ Schneckloth v Bustamonte 412 US 218, 93 S. Ct. 2041 (1973). The case is not without its critics: note in particular Justice Marshall's dissent. See also, e.g., A Pratt, "The need for 'knowing': Why the Iowa Supreme Court should reject Schneckloth v. Bustamonte" (2015) 100 Iowa LR 1327.

${ }^{134}$ Schneckloth at 2077.

${ }^{135}$ Dedman at para [63] per Le Dain, J.

${ }^{136}$ Meates at 346.

${ }^{137}$ D Dixon, D Coleman, and K Bottomley, "Consent and the legal regulation of policing" (1990) J L and Society 345 at 348. 
answer to that request may be either yes or no" to be simply inaccurate. ${ }^{138}$ A requirement to inform the person of their right to refuse cannot be viewed as an unreasonable burden upon the police. ${ }^{139}$ As Justice Marshall concluded, to do otherwise would permit "a game of blindman's buff, in which the police always have the upper hand, for the sake of nothing more than the convenience of the police". 140

It is also worth noting that research shows that at least some officers viewed refusing a search as grounds to move to a statutory stop and search. ${ }^{141}$ This is clearly incorrect and serves to undermine the entire concept of consent as the basis for the non-statutory power in such cases.

The other major issue with consent arises from the extensive use of the non-statutory power on children. Since June 2014 the power is nominally not meant to be exercised on those aged under twelve. ${ }^{142}$ Previously, children as young as six were subjected to nonstatutory stops and searches, with approximately 500 children aged under ten stopped and searched in 2010. ${ }^{143}$ Indeed, "young people are significantly more likely to be searched on a non-statutory basis". ${ }^{144}$ It is questionable whether a young child can fully understand the consequences of permitting the police to search them. If they are not fully informed, consent is not valid.

A more basic problem is whether young, especially very young, children can in law consent to a non-statutory search. Certainly those under eight - the age of criminal responsibility - must be incapable of such consent. It is, however, difficult to establish where a bright-line may lie for older children. One overarching problem is how to frame the interaction, as criminal or civil law. On the one hand, consent enables the police to perform actions that would otherwise be delicts; on the other, the child may be subject to criminal prosecution due to evidence found during the search. Whichever framework is used, there are

${ }^{138}$ R Delsol, Institutional Racism, the Police and Stop and Search: A Comparative Study of Stop and Search in the UK and USA (unpublished PhD Thesis, University of Warwick, 2006) 116.

${ }^{139} \mathrm{Cf}$ Schneckloth at 2057 but note the dissent of Mr Justice Marshall, n 12 at 2078.

${ }^{140}$ Schneckloth at 2079.

${ }^{141}$ Murray (n 5) 4.

${ }^{142}$ Scottish Parliament Justice Sub-Committee on Policing, 19 June 2014: see Scottish

Parliament, Official Report col 460 (19 June 2014); but cf M Ellison, "Police search hundreds of children despite commitment" (BBC, 4 Feb 2015: http://www.bbc.co.uk/news/uk-scotland31022269).

${ }^{143}$ Murray (n 5) 24.

${ }^{144}$ Ibid. 
no direct precedents. Under sections 1-2 of the Age of Legal Capacity (Scotland) Act 1991, children under the age of sixteen have legal capacity to enter into any "transaction" if it is of a kind that is normally entered into by persons of that age and circumstances. There is (thankfully) no need to argue that the substantial usage of stop and search on young persons means it is a "normal transaction", as the 1991 Act does not alter the delictual or criminal responsibility of any party, both of which are potentially engaged. Therefore, the common law age of consent may be the appropriate benchmark: this is the age of minority, or puberty, fourteen for boys and twelve for girls. ${ }^{145}$ In 2010, subject to the caveats regarding data (in)accuracy, 26,000 children under fourteen were stopped and searched under the nonstatutory power. ${ }^{146}$ If the common law age of consent is the appropriate test, many of these were unlawful. Even if this is not the correct test, and these children had the capacity to consent, for the reasons above doubts remain regarding the validity of the consent.

People may also lack capacity to consent through, for example, mental illness or intoxication. Neither category has been flagged as problematic in empirical research to date. However, given the use of the power in relation to alcohol and young persons, its use on intoxicated youths seems possible if not probable.

Leaving consent to one side, it is doubtful that non-statutory stop and search is prescribed by law. While non-statutory stop and search has (obviously) no statutory base, there is no requirement of codification, and as the use of this power has been acknowledged in case-law there will be a basis in law. ${ }^{147}$ However, it is questionable whether the power is "formulated with sufficient precision to enable the citizen - if need be, with appropriate advice - to foresee, to a degree that is reasonable in the circumstances, the consequences which a given action may entail". ${ }^{148}$ In particular the lack of a requirement to inform the person that they may refuse the search and the fact that some officers view refusal as grounds for a suspicion-based statutory stop cast doubt upon its foreseeability. Also, Malone v United Kingdom suggests that, contrary to the position under domestic law, ${ }^{149}$ an interference with a Convention right requires a positive authorisation; the mere fact that the interference is not illegal is insufficient. ${ }^{150}$ Although, as Mead notes, "given the consequences, it is not hard to

\footnotetext{
${ }^{145} \mathrm{~K}$ Norrie, The law relating to the parent and child in Scotland (2013) para 1.11.

${ }^{146}$ Murray (n 5) 21.

${ }^{147}$ Sunday Times $v$ United Kingdom (1979) 2 EHRR 245 para [47].

${ }^{148} S v$ UK (2009) 48 EHRR 50 [95]. See also Huvig v France (1990) 12 EHRR 528.

${ }^{149}$ See Malone v Metropolitan Police Commissioner [1979] Ch 344.

${ }^{150}$ Malone v United Kingdom (1991) 13 EHRR 448.
} 
imagine a court ... feeling constrained in holding ... the 'lawfulness' test to include nonproscription as well as positive proscription". ${ }^{151}$

Even if the foreseeability requirement is met, there are clearly insufficient safeguards against the arbitrary exercise of the power. The absence of adequate recording or review mechanisms, discussed above, means that the only significant safeguard is consent. While consent could bring the power within a different paradigm, it is highly unlikely that the ECtHR would view consent as a sufficient safeguard, particularly given the issues outlined above. Although not on all fours with Colon or Gillan - notably, the non-statutory power nominally lacks the coercive element evident in both - this near-total absence of safeguards means there is a clear risk of arbitrariness. Unlike Colon, there is no independent evidence of effectiveness to which to point. Indeed, the detection rate for non-statutory stop and search, which was $8 \%$ in 2010 , suggests ineffectiveness, if detection is taken as the objective. The ECtHR are likely to be concerned by the practice, notably the extensive use of the power, which has accounted for approximately $70 \%$ of all stops and searches between 2005 and $2013^{152}$ (despite the plethora of statutory powers), as well as the prevalence of its use on young people. For example, 37,233 sixteen years olds were stopped in 2010 in the Strathclyde area, which at the time had 26,476 sixteen year old residents, resulting in the staggering stop rate of 1,406 per 1,000 of the population. ${ }^{153}$ All this combines to show a clear risk of the arbitrary exercise of the power. It therefore seems highly unlikely that the power would deemed to be prescribed by law.

\section{CONCLUSION}

Scottish stop and search powers are in urgent of reform. This article has argued that two of the three categories - non-statutory and suspicionless statutory - are likely to be in breach of the ECHR, with the final category evidencing poor practice providing insufficient protection to the public and insufficient guidance to officers. Scotland would do well to incorporate the limitations to section 60 of the Criminal Justice and Public Order Act, detailed in the BUSS,

${ }^{151}$ D Mead, "Informed consent to police searches in England and Wales - a critical (re)appraisal in light of the Human Rights Act" (2002) Crim LR 791 at 795.

152 Murray (n 5) 10. The proportion has dropped significantly since 2013 see further Murray (n 6).

${ }^{153}$ Murray (n 5). 
to ensure it is prescribed by law. The non-statutory power is virtually unfettered and unlikely to be prescribed by law. It should be prohibited. Alternative powers exist which are subject to greater oversight and protection against arbitrary deployment. More generally, a detailed and binding code of practice should be adopted. This should include a clearer exposition of reasonable suspicion and require officers to, inter alia, inform the person stopped of their name or warrant number, the reason for the search, and to issue them with a stop form. A systematic and routine review structure is urgently needed and data collection and correlation must be improved to facilitate this.

There is a broader lesson here, namely the need for routine publication of accurate and appropriate data on the use of police powers. A spotlight was shone on stop and search through Murray's doctoral research, with her FOI requests revealing the substantial rate of stop and search in Scotland and prompting her deeper analysis. Oversight of such important powers should not rely on the chance choice of a research topic (one which was not even her original choice). Greater transparency and routine publication of core data will assist both oversight bodies, such as the Scottish Police Authority and HMICS, and academics in identifying potentially problematic trends or practices that merit closer scrutiny and those evidencing best practice. 